\title{
Intraoperative Neurophysiological Monitoring in Cerebello Pontine Angle Tumor
}

\author{
Sang-Ku Park \\ Department of Neurology Laboratory, Samsung Medical Center, Seoul 135-710, Korea
}

\begin{abstract}
Intraoperative Neurophysiological Monitoring (INM) inspection has a very important role. While preserving the patient's neurological function be sure to safe surgery, neurological examination should thank. Cerebello pontine angle tumor surgery, especially in the nervous system is more important to the meaning of INM. In cochlear nerve, facial nerve, trigeminal nerve, which are intricate brain surgery, doctors are only human eye and brain to the brain that it is virtually impossible to distinguish the nervous system. They receives a lot of help from INM. In this paper, we examined six kinds broadly. First, the methods of spontaneous EMG and Free-running EMG, which can instantly detect a damage inflicted on a nerve during surgery. Second, methods of triggered EMG and direct nerve electrical stimulation, which directly stimulate a nerve using electricity to distinguish between nerves and brain tumors. Third, the method of knowing a more accurate neurologic status by informing neurological surgeons about Free-running EMG wave forms that are segmetalized into four. Fourth, three ways of knowing when a patient will be awaken from intraoperative anesthesia, which happens due to a weak anesthetic. Fifth, a method of understanding the structures of a brain tumor and a facial nerve as five dividend segments. Sixth, comparisons between cases normal facial nerve recovery and occurrence of a facial nerve paralysis during the postoperative course.
\end{abstract}

Keywords: Intraoperative neurophysiological monitoring, Spontaneous EMG, Free - running EMG, Triggered EMG, Direct nerve electrical stimulation

This is an Open Access article distributed under the terms of the Creative Commons Attribution Non-Commercial License (http://creativecommons.org/licenses/by-nc/3.0) which permits unrestricted non-commercial use, distribution, and reproduction in any medium, provided the original work is properly cited

Copyright (C) 2014 The Korean Society for Clinical Laboratory Science. All rights reserved.
Corresponding author: Sang-Ku Park Department of Neurology Laboratory, Samsung Medical Center, Seoul 135-710, Korea. Tel: 82-2-3410-2737 E-mail: sk39.park@samsung.com

Received: February 22, 2014 Revised: March 22, 2014 Accepted: March 23, 2014

\section{서 론}

수술 중 신경계 감시검사(Intraoperative Neurophysiological Monitoring, INM)는 신경계 수술에서 광범위하게 이용되어 수술 중 신경계의 손상을 조기에 찾아서 수술 후의 합병증을 줄이며 수 술 중 외과의사가 안전하게 수술을 하고 있다는 확신을 줄 수 있고, 고위험군의 수술을 안전하게 시행할 수 있게 도움을 준다. 소뇌교 각 종양수술 중에서도 특히 전정신경초종(vestibular schwannoma)에서 수술 후 안면신경마비가수술 중 신경계 감시검사를 시 행한 군에서 현저히 감소한다고 알려져 있다(Harner 등, 1988; Leonetti 등, 1989; Niparko 등, 1989) (Fig. 1).

소뇌교각 종양수술이 모두 끝난 후 환자가 회복실에서 마취가 깨었을 때 뇌종양수술 제거로 인한 안면신경의 손상이 발생하여서 한쪽 얼굴을 전혀 못 움직이는 일은 없어야만 한다. 하지만 신경계
추적감시 검사 업무를 하는 여러 병원에서 수술 중에는 특별한 파 형이나 문제점이 전혀 발견되지 않았으나 수술 이후에 환자가 안면 신경이 매우 심각한 손상을 받아서 사회생활을 하지 못할 정도가 되었다는 말을 종종 듣는다. 삼성서울병원에서도 이와 같은 일을 경험한 적이 있고, 소뇌교각 종양수술 신경계 추적 감시 검사 중에 서 안면 근전도 검사에 대해 좀 더 자세하게 살펴볼 필요가 있다고 사료되어 본 논문을 쓰게 되었다.

\section{재료 및 방법}

\section{1. 검사장비}

수술장에서 사용하는 신경계추적감시(INM)검사장비는 Xltek Protektor (Natus Medical Incorporated Excel Tech Ltd., XLTEK, Canada)를 사용하였다. 근전도(Electromyography, EMG) 


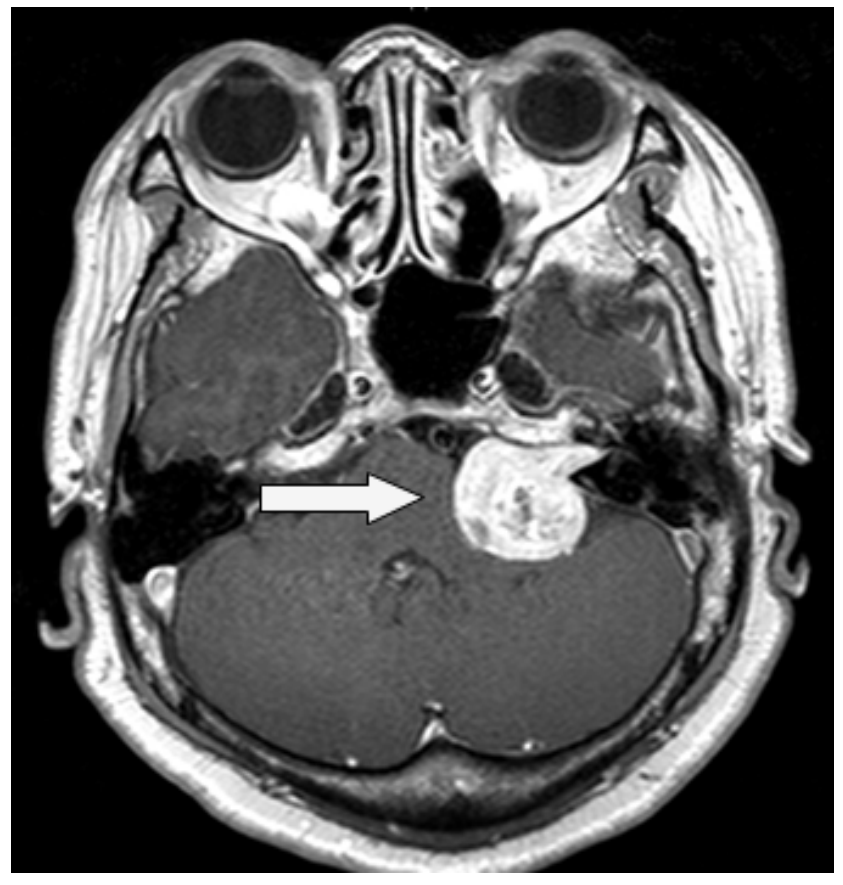

Fig. 1. MRI of vestibular schwannoma.

검사 setting은 Range $\pm 50 \mathrm{mV}$, Reject Threshold $\pm 15 \mathrm{mV}$, LFF/HFF: 10 Hz/3 KHz, Timebase 100 150 ms/div, Amplitude $100 \mu \mathrm{V}$ 로 설정하여 검사를 하였다.

\section{2. 검사방법}

2013년 1월부터 2014년 2월까지 소뇌교각 종양환자 12명을 대 상으로 분석을 하였다. 나이는 28세에서 71 세로 평균 54.3 세 였고, 남자 6명, 여자 6명이었다. 종양의 세포학적 성상을 보면 청싱경초 종(vestibular schwannoma)이 10명, 표피낭종(epidermoid cyst) 이 1명, 혈관아세포종(hemangioblastoma)이 1명 이었다(Table 1). 근전도 검사는 뇌신경에 의해 지배를 받는 근육에 침전극(Subdermal needle electrode)을 부착을 하여 파형분석을 하며, 수술 중 신경손상이 발생할 때마다 바로 감지가 가능한 자유진행 근전도 방법(spontaneous EMG, Free-running EMG)과 직접 신경을 전 기자극하여 신경과 뇌종양을 구별하는 방법(triggered EMG, direct nerve electrical stimulation)이 있다.

먼저 자유진행 근전도 방법(spontaneous EMG, Free-running $\mathrm{EMG}$ )에 대해 살펴보자.

자유진행 근전도는 뇌신경을 수술 중에 건드리면 뇌신경이 담당 하고 있는 말초 근육이 움직이는 원리를 이용하는 것으로 말 그대 로 안면근육에 꽂아 놓은 전극으로부터 발생하는 근전도 파형을 관 찰하는 것이다. 수술 중에 자유진행 근전도 파형이 관찰되면 파형 의 모양을 보고 어떠한 상태인지를 파악하여 수술하는 집도의에게
Table 1. General characteristics in 12 patients

\begin{tabular}{lc}
\hline \multicolumn{1}{c}{ No. of patients } & 12 \\
\hline Female:male (ratio) & $6: 6(1: 1)$ \\
Mean age (yrs) & $28 \sim 71(54.3)$ \\
vestibular schwannoma & 10 \\
epidermoid cyst & 1 \\
hemangioblastoma & 1 \\
\hline
\end{tabular}

바로 알려야 뇌신경의 손상을 최소화 할 수 있다. 수술하는 동안 근 전도 파형이 '관찰 된다' 또는 '관찰 안 된다'로 알리면 뇌신경의 상 태를 정확하게 집도의는 파악하기 어렵다. 그래서 자유진행 근전도 파형을 좀 더 세분화 하여 알리면 신경학적으로 보다 정확한 상태 파악을 하여 안전한 수술에 도움을 많이 줄 것이라 생각한다. 그래 서 근전도 파형을 다음의 네 가지로 구분하여 알릴 것을 제안 한다.

첫째, 신경손상으로 인하여 발생하는 지속적인 긴장성변화 (tonic activity)로서 파형의 진폭이 작고 매우 일정한 간격으로 관 찰될 때에는 뇌신경이 옆으로 밀리거나 앞으로 당겨지고 있는 상태 이다(Fig. 2a).

둘째, 파형의 진폭이 일정하지 않고 불규칙적으로 가끔씩 관찰 될 때에는 뇌신경이 아주 약하게 간접적인 영향을 받는 상태이다. 보통 이러한 파형이 관찰이 되면 한두 시간 후에는 뇌신경이 관찰 된다. 즉, 뇌신경에 가깝게 접근은 하였지만 직접적인 영향을 받지 는 않는 상태이다(Fig. 2b).

셋째, 군집성변화(burst activity)는 신경축삭(axon)의 기계적 수용체(mecha noreceptor)의 자극 때문에 발생하는 일시적인 현 상으로 파형의 진폭이 매우 크고 일정하지 않고 불규칙적인데 집도 의가 수술 부위를 건드릴 때 마다 파형이 나오는 상태이다. 이러한 경우는 건드리는 수술 부위가 바로 뇌신경에 해당한다. 즉, 뇌종양 과 뇌신경이 서로 복잡하게 얽혀있어서 육안으로 뇌신경이 보이지 않아서 집도의는 뇌종양이라 생각하고 수술을 하는 상태로 매우 위 험한 상태이므로 빨리 알려야만 한다(Fig. 2c).

넷째, 파형의 간격이 매우 좁고 일정하며 특유의 고음소리가 나 는 경우로 뇌신경이 심각한 손상을 받아서 발생하는 빠르게 파형이 형성(high frequency)되면서 지속적인 긴장성변화(tonic activity) 파형이다. 이러한 상태가 지속되면 뇌신경을 대부분 꼲어지거나 기 능을 상실한다(Fig. 2d).

이러한 4 가지의 근전도 파형과 매우 유사하지만 뇌신경의 영향 으로 발생하지 않고, 수술 기구들에 의해 영향을 받는 경우도 있다. 잡파(artifact)로서 이러한 경우 구별하는 방법은 파형들이 한 시점 에 모두 나타거나, 파형모양이 서로서로 모두 비슷하거나, 수술 부 위를 건드릴 때 파형이 형성되는 것이 아니라 수술 이외에 다른 동 작을 할 때 파형이 형성된다(Fig. 3). 


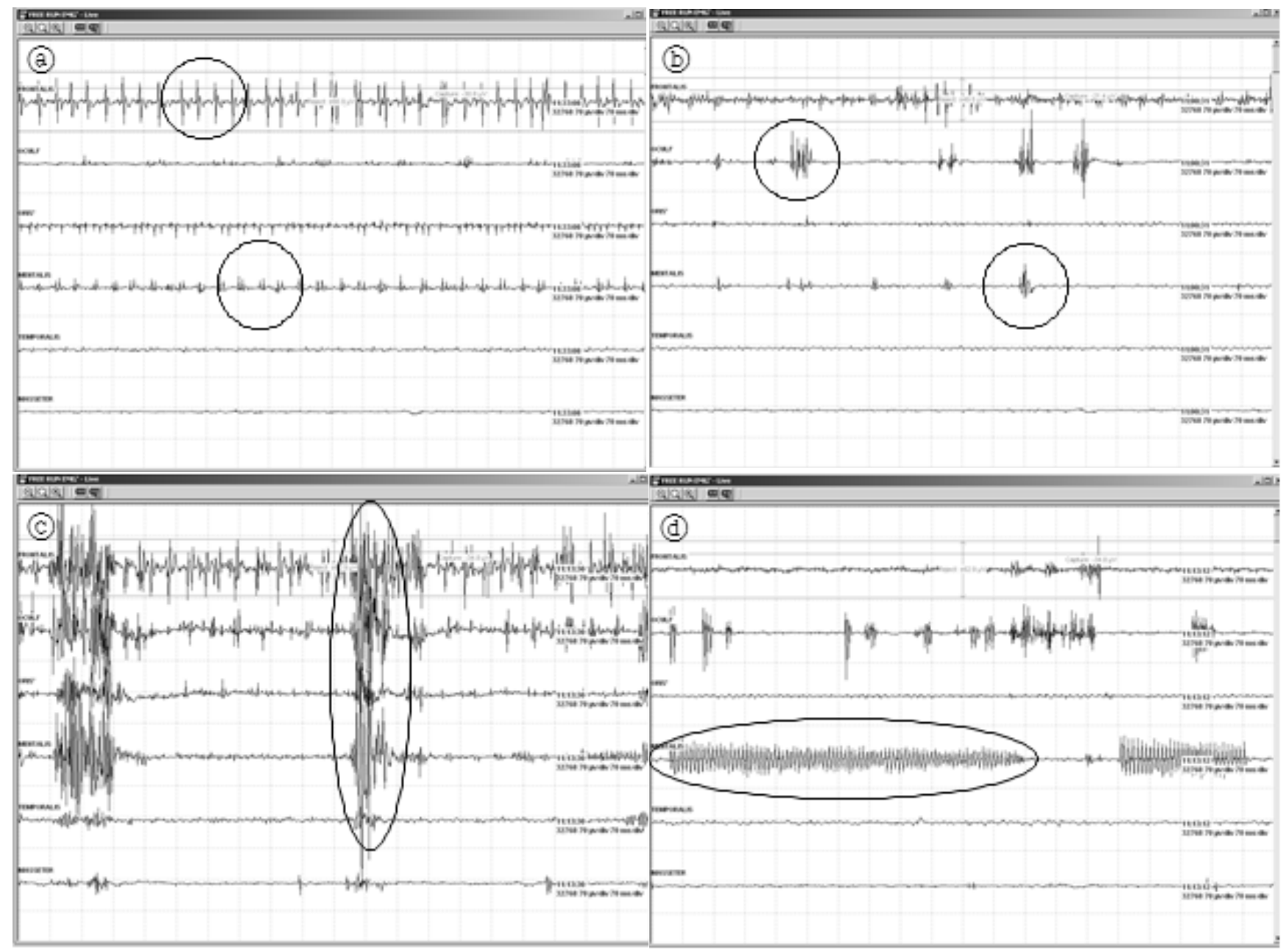

Fig. 2. Free-running electromyography patterns.

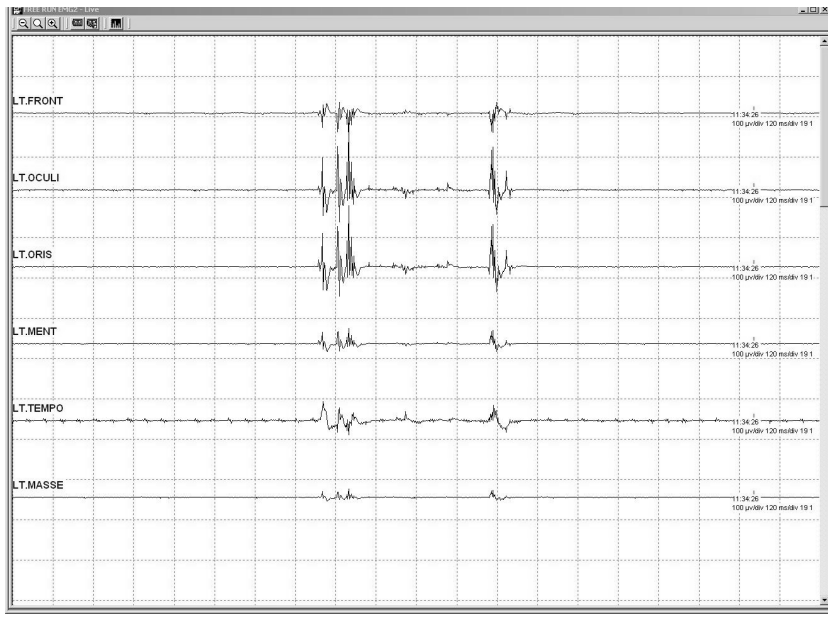

Fig. 3. Artifact of Free-running electromyography.

이와는 반대로 수술부위를 건드릴 때 발생하는 잡파로는 전기소 작기(electrocautery)를 이용할 때의 파형인데 이 경우는 여러 채 널에서 동시에 매우 큰 파형이 형성되며 날카로운 소리가 나므로
쉽게 구별을 할 수 있다(Fig. 4).

이번에는 직접 신경을 전기자극하여 신경과 뇌종양을 구별하는 방법(triggered EMG, direct nerve electrical stimulation)에 대 하여 살펴보자.

수술 중 수술시야에서 보이지 않는 종양주위에 안면신경의 위치 를 확인하기 위하여 신경근을 직접 전기자극을 시행하여 안면신경 위치를 확인한 후 그 부위를 피해서 종양 절개를 가할 수 있다. 그래 서 종양을 절제하면서 안면신경에 손상을 주지 않으면서 종양을 제 거하여 수술 후의 안면마비 발생을 줄일 수 있다(서대원, 2007).

종양 제거 후 종양이 존재하던 부위의 안면신경 양쪽 끝자락에 전기자극을 주어서 유발되는 역치를 비교하여 안면신경의 손상 정 도를 확인할 수 있다. 단, 이때 전기자극은 뇌척수액(CSF) 또는 Saline으로 인하여 젖은 환경에서 옆으로 전기자극이 번지는 션트 (shunt)의 가능성 때문에 constant voltage 방법을 사용하며, 단극 성(monopolar stimulator) 자극을 이용하는 것이 좋으며 1-5 volt 이하에서 자극하는 것이 좋다(Traynelis 등, 1994). 

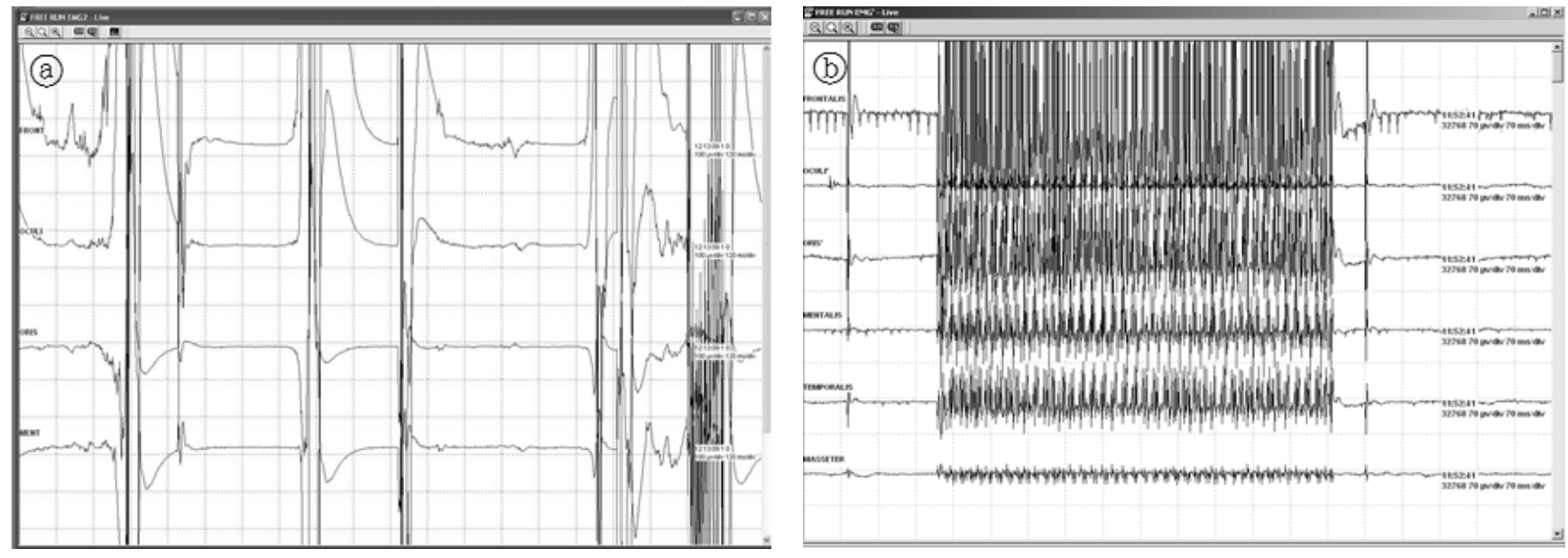

Fig. 4. Artifact of Electrocautery (a) bipolar stimulation, (b) monopolar stimulation).
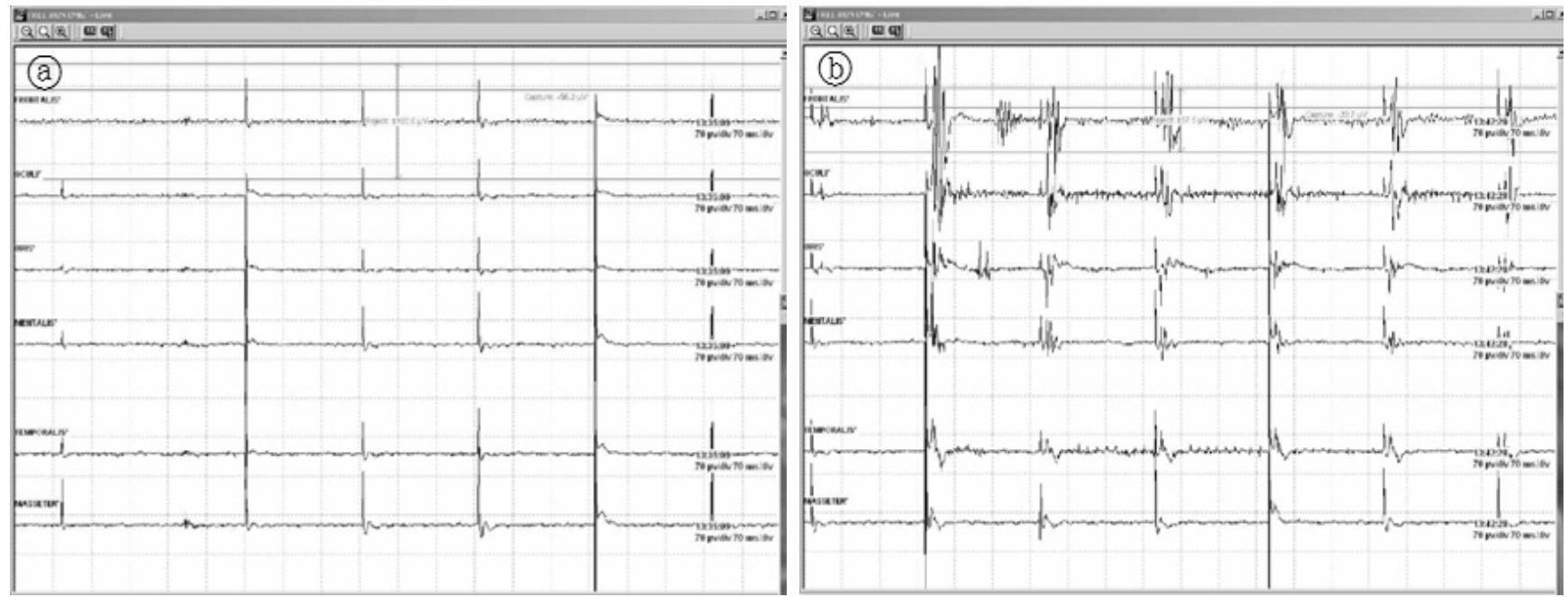

Fig. 5. Wavies of Direct nerve electrical stimulation.

Stimulator를 종양부위에 자극을 하면 종양 또는 근육부위일 경 우 Stim-artifact만 관찰이 되고, 아무런 소리도 안 난다(Fig. 5a). 하지만 뇌신경을 자극하게 되면 해당하는 근육으로부터 중저음의 큰 소리와 함께 근전도가 전기자극이 들어갈 때마다 관찰이 된다 (Fig. 5b).

\section{3. 마취의 영향}

수술은 전신마취 하에 이루어지므로 마취의 심도에 파형이 영향 을 받는다. 마취의 심도가 너무 깊으면 뇌신경을 건드려도 해당근 육에서 근전도 파형이 형성 안 된다. 그러므로 척골신경을 4 번 연속 적으로 자극한 후 엄지손가락의 움직임을 관찰하는 사연속자극 (train of four, TOF)검사가 적어도 2번 이상 되도록 근이완제 (neuromuscular blocking agent)의 양을 적절히 유지하는 것이 중요하다. 신경계 감시 검사를 위하여 마취과에서 마취의 심도를
너무 낮게 유지할 경우에 가끔 수술 중에 환자가 깨기도 한다. 수술 중 환자의 의식이 깨어나게 되면 수술 부위로 인한 극심한 통증을 순간적으로 매우 크게 느끼게 되고, 자발호흡을 하려 하지만 기도 삽관이 되어있어서 원활하게 호흡을 할 수 없는 상태여서 매우 짧 은 시간에 혈압이 최고치에 오르게 되고, 심박동수는 매우 빠르게 바뀐다. 자칫 수술로 인하여 연약한 부위가 외부에 노출이 되어있 는 상태라면 혈압의 급상승으로 뇌혈관이 파열될 수도 있다. 그러 므로 마취과에서는 수술 중에 환자가 깨게 되면 다량의 마취제를 투여하여 깊은 마취상태로 빨리 만들어서 환자를 안정상태로 만든 다. 이렇게 되면 마취의 심도가 너무 깊은 상태로 되어서 신경계 검 사를 한동안 할 수 없게 되고 수술도 신경계의 평가를 못하면서 진 행해야만 한다(park 등, 2012). 이러한 경우는 최악의 경우로서 환 자가 갑자기 벌떡 깨는 것이 아니라 전조증세가 항상 수반되는데 다음의 세 가지로 분류할 수 있다. 


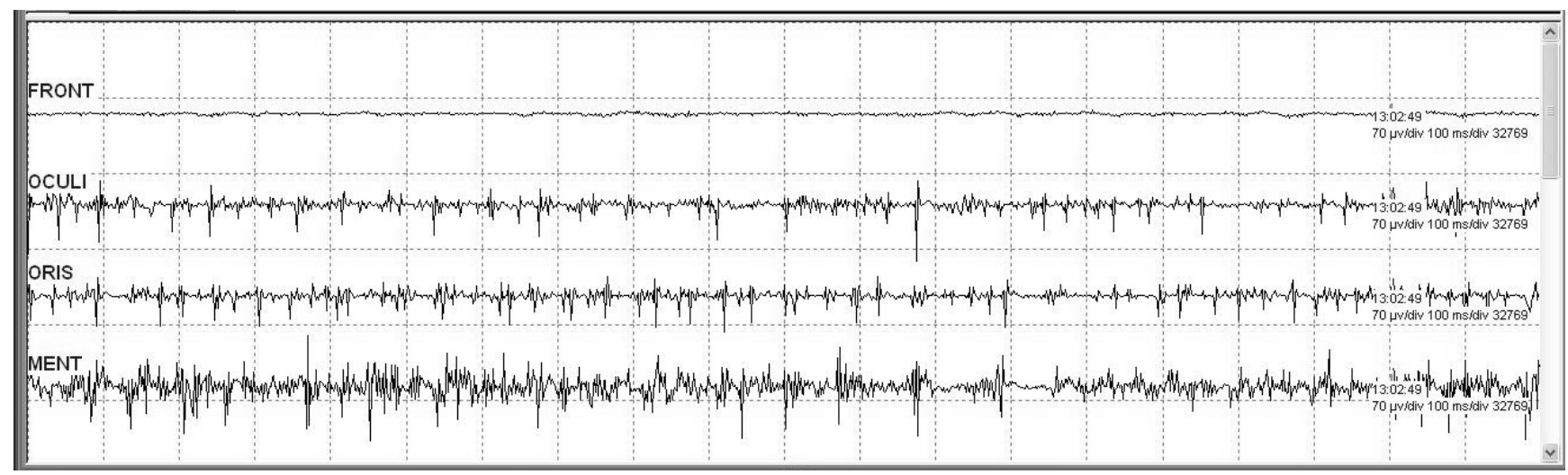

Fig. 6. Electromyography of self activity.

첫째, 환자의 호흡곡선에 자발호흡의 조짐이 관찰된다. 둘째, 혈 압이 서서히 오른다. 셋째, 자유진행 근전도(spontaneous EMG, Free-running EMG)파형이 매우 약하게 지속적으로 관찰된다. 이 러한 세 가지 변화 중에서 자유진행 근전도 파형이 수술과 상관없 이 지속적으로 관찰이 된다면 환자가 깨기 전의 마취가 약해진 상 황일 수 있으므로 마취과와 긴급히 상의를 해볼 필요가 있다. 이러 한 경우에 신경계 감시검사의 경험이 없는 선생님들이 수술로 인하 여 뇌신경을 건드려서 근전도 파형이 형성된 것이라고 생각을 하여 집도의에게 알리게 되면, 집도의는 수술로 인하여 신경을 건드렸다 고 오해하는 경우가 종종 발생하게 되어 수술의 방향이 엉뚱하게 흐를 수 있다(Fig. 6).

\section{결 과}

\section{1. 종양과 안면신경의 관계}

소뇌교각 수술은 뇌종양과 안면신경이 복잡하게 얽혀있어서 수 술 중에 안면신경의 주행 경로를 찾아서 안전하게 보호하는 것이 매우 중요하다. 이렇게 복잡한 뇌종양과 안면신경의 구조를 크게 다섯 가지의 구조로 분류하여 살펴보자.

첫째, 뇌종양이 안면신경 위에서 서서히 자라서 안면신경을 종양 밑에 깔고 있는 상태로, 뇌종양을 모두 제거하기 전까지 안면신경이 보이지 않는 경우이다. 수술을 진행하면서 대부분 안면신경을 건드 려서 근전도 파형이 조금씩 관찰이 되어야 하지만, 이러한 경우는 어 떠한 근전도 파형도 관찰이 되지 않는다. 그래서 수술을 진행하는 집 도의는 안면신경이 수술 중 심각한 손상을 입었거나, 꼲어졌는지 몰 라서 초조해 한다. 종양제거가 모두 되어갈 때쯤에 근전도 파형이 관 찰되며 종양 밑에 있던 안면신경이 관찰이 된다(Fig. 7a).

둘째, 뇌종양이 안면신경을 옆으로 밀어내면서 서서히 자라는 경우로 해부학적으로 안면신경이 있어야 할 위치가 아닌 전혀 새로 운 위치에 존재하기 때문에 수술하는 동안에 근전도 파형의 관찰이
매우 중요하다. 종양을 기준으로 12시, 3시, 6시, 9시 방향을 건드 릴 때, 유독9시부분에서만 근전도 파형이 관찰된다면 그 부분에 안 면신경이 지나가고 있는 것이다. 이런 경우 직접신경전기자극검사 를 진행하면 유발되는 근전도 파형을 잘 관찰할 수 있고, 안면신경 도 잘 보존하면서 종양제거를 할 수 있다(Fig. 7b).

셋째, 뇌종양이 안면신경을 감싸면서 형성되는 경우로 쉽게 설 명하자면 핫도그 스틱이 안면신경이고 핫도그 튀김부분이 뇌종양 인 것처럼 형성된 경우이다. 이러한 경우 안면신경이 직접적으로 보이지는 않지만 종양을 당기거나 옆으로 밀게 되면 근전도 파형이 관찰된다. 직접신경전기자극검사를 시도해 보아도 근전도 파형은 관찰되지 않는다. 그러므로 안면신경이 어디에 있는지 몰라서 혼란 이 발생한다(Fig. 7c).

넷째, 뇌종양 위에 안면신경이 위치하는 경우로, 뇌종양을 제거 하기 위해 종양을 처음으로 건드릴 때부터 근전도 파형이 관찰된 다. 뇌종양과 안면신경위로 얇은 막으로 덮여있어서 육안으로는 그 냥 종양만 있는 것으로 보이므로 매우 주의해야 한다. 그래서 이러 한 경우를 항상 염두 해 두고 종양 제거를 하기 전에 종양위를 광범 위하게 직접신경전기자극검사를 시행하여 아무런 근전도 파형이 유발되지 않는 것을 확인한 후 종양제거를 하는 것이 좋다(Fig. 7d).

다섯째, 뇌종양이 안면신경을 옆으로 또는 아래로 밀어내면서 자라다가 안면신경이 종양의 영향으로 구조적으로 납작해지면서 매우 얇고 평평해진 경우이다. 이러한 경우 안면신경은 너무 얇아 서 육안으로는 구분이 안 된다. 또한 직접신경전기자극검사를 시행 하여도 유발되는 근전도 파형이 관찰 안 된다. 하지만 수술을 진행 하는 과정에서 매우 진폭이 작은 근전도 파형이 불규칙적으로 계속 관찰이 된다. 이러한 상황이 지속되면서 수술을 진행하게 되면 결 국 안면신경은 끊어지게 된다. 집도의 입장에서는 직접신경전기자 극검사에서 파형이 유발되지 않았으므로 안면신경이 아니라고 판 단하게 되고, 검사자 입장에서는 자유진행근전도 파형이 너무나작 고 불규칙적으로 관찰이 되므로 안면신경이 손상되리라 예측하기 


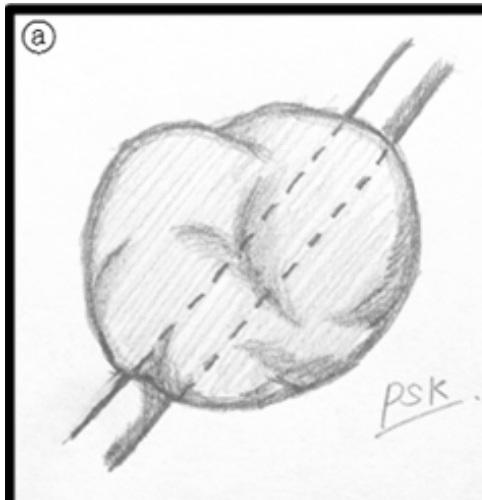

(d)

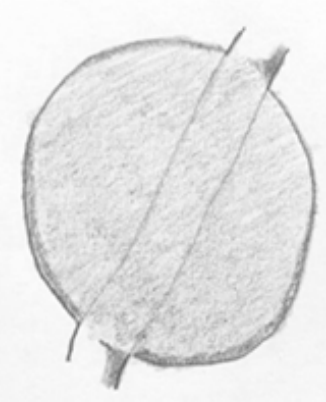

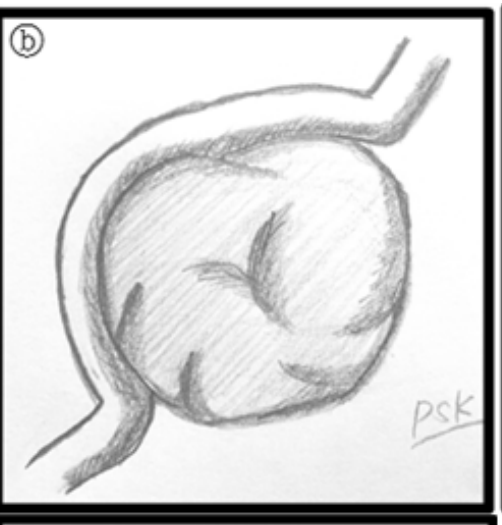

(e)-1

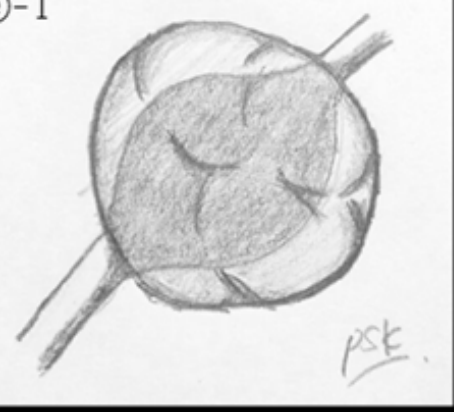

(C)

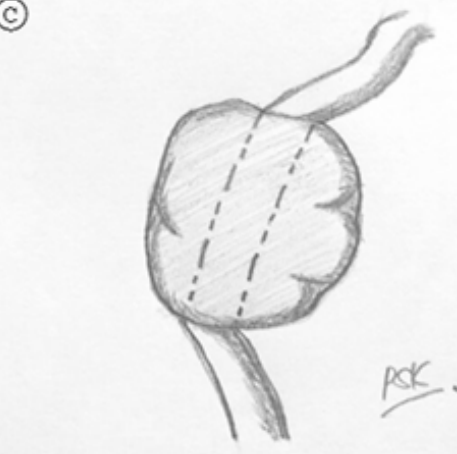

(e)-2

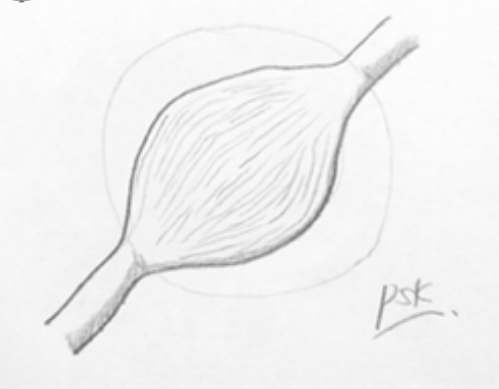

Fig. 7. Various structures of the tumor and the facial nerve.

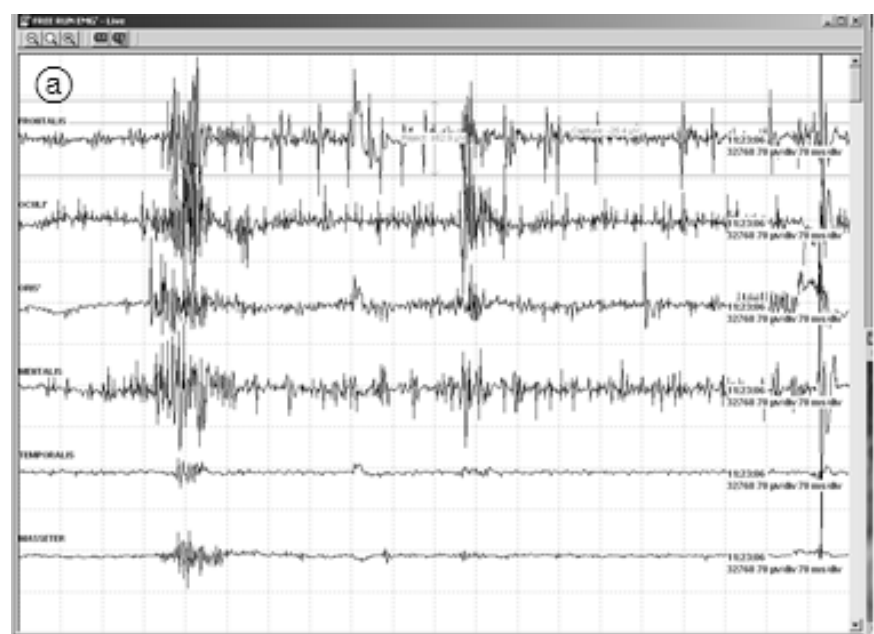

Fig. 8. Observed waveform is well shown case.

어렵다(Fig. 7e-1,2).

\section{2. 수술 중 안면신경 검사}

다음은 수술 중 검사의 파형과 수술 후 환자의 안면신경 상태를 비교 평가해 보려고 한다. 첫째, 수술 후 환자의 안면신경상태가 수 술 전과 다름없이 매우 좋은 경우는 수술 중 자유진행 근전도 파형 이 매우 잘 관찰되고(Fig. $8 \mathrm{a}$ ), 직접신경전기자극 검사를 하여도 안 면신경에서 유발되는 파형이 매우 잘 관찰이 되는 경우가 대부분

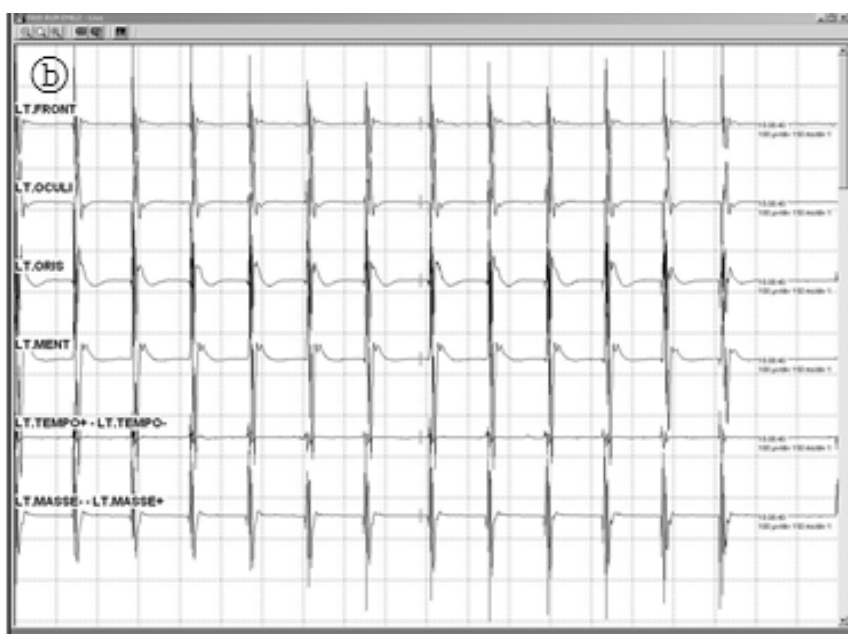

많았다(Fig. 8b).

이렇게 뇌종양 제거 중에 특정부위를 중심으로 자유진행 근전도 파형이 약하게 관찰이 되면 집도의에게 검사자는 바로 알려야 한 다. 그래야만 뇌신경의 주행 경로가 어디쯤인지 집도의가 감을 잡 고 수술을 할 수 있다. 자유진행 근전도 파형이 강하게 관찰되면 집 도의에게 뇌신경을 직접적으로 건드리고 있다고 말을 하고 직접신 경전기자극 검사를 권유하여 안면신경을 확실하게 찾는 것이 안면 신경의 보존에 매우 큰 도움을 준다. 위와 같은 흐름으로 수술이 진 
행이 되었던 경우를 살펴보면 수술 후 환자의 안면신경상태도 대부 분 좋았다.

둘째, 수술 전과는 다르게 수술 후에 안면신경의 손상이 심각하 였던 경우를 살펴보면, 앞에서 거론한 결과 1 의 다섯 번째에 해당하 는 안면신경이 종양으로 인하여 납작하게 펼쳐져서 육안으로 구분 이 안 되는 경우가 대부분 해당이 되었다. 이러한 경우는 삼성서울 병원에서도 경험을 하였고, 타 병원으로 부터 여러 차례 문의를 받 은 적이 있는 것으로 보아 가장 힘든 수술이라고 생각이 되며, 특히 환자의 안면신경 손상이 너무나 심각하게 되기 때문에 이러한 경우 의 파형을 자세히 살펴봄으로써 더 이상의 안면신경 손상환자가 없 기를 바란다.

종양을 제거하는 과정에서 자유진행 근전도 파형이 관찰이 되긴 하나 진폭이 너무나 작아서 파형이라고 생각하지 못하는 경우가 종 종 있다(Fig. 9a). 수술이 진행되면서 자유진행 근전도 파형의 진폭 이 좀 더 크게 관찰이 된다. 이정도의 근전도 파형은 뇌종양 밑에 안 면신경이 존재 할 때에도 종양에 의해 안면신경이 눌리면서 발생하
는 근전도 파형이라고 착각하기 쉽다. 직접신경전기자극 검사를 시 행하여도 근전도 파형이 유발되지 않으므로 안면신경이 아니라 종 양이라고 생각할 수 있다. 이러한 이유는 안면신경이 너무나 얇게 종이처럼 펴져 있어서 전기자극에 의해 안면신경 자체가 흥분되지 않는 것으로 생각이 된다(Fig. 9b). 시간이 더 지나면서 신경손상으 로 인하여 발생하는 지속적인 긴장성변화(tonic activity)파형이 관찰이 된다면 안면신경의 손상이 심각할 것을 예측할 수 있다. 이 럴 경우 더 이상의 수술 진행을 하기보다는 종료할 것을 권고한다. 또는 아주 작은 자유진행 근전도 파형이라도 관찰이 안 되는 부분 을 찾아서 그곳만 수술할 것을 권장한다(Fig. 9c). 지금까지의 모든 자유진행 근전도 파형을 무시하고 수술을 계속하였다면, 파형의 간 격이 매우 좁고 일정하며 특유의 고음소리가 나는 뇌신경이 심각한 손상을 받아서 발생하는 빠르게 파형이 형성(high frequency)되 면서 지속적인 긴장성변화(tonic activity) 파형을 보게 될 것이고 이러한 파형이 관찰된다면 수술 후에 심각한 안면마비증세가 발생 할 것이다(Fig. 9d).
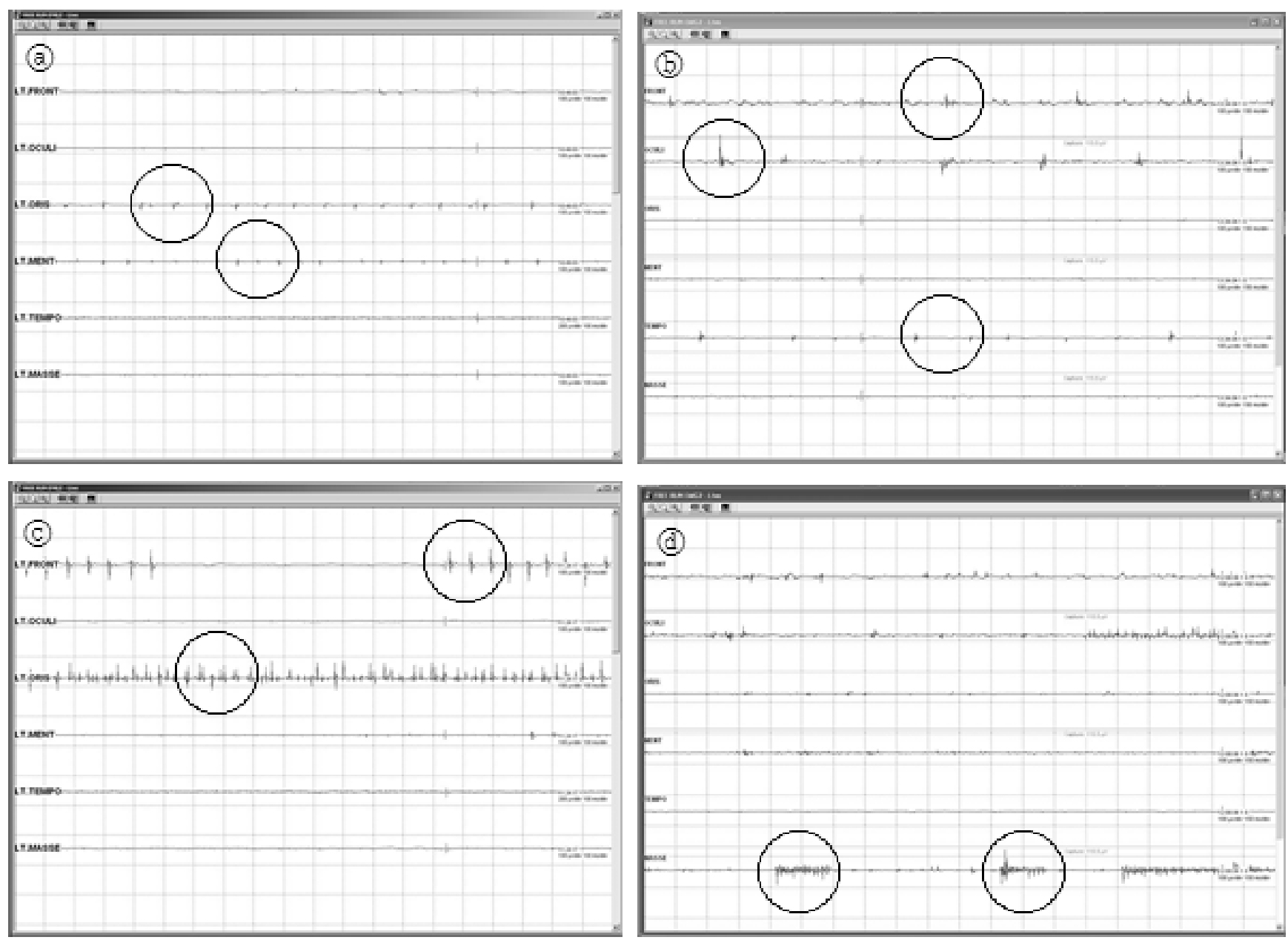

Fig. 9. Observed waveform is difficult shown case. 


\section{고 찰}

수술 이후에 안면마비가 심각하게 발생하면 환자는 해당부위 쪽 의 눈을 감지 못한다. 눈이 시려서 눈물이 계속 흐르지만 스스로 눈 을 감지 못하므로 환자는 어쩔 수 없이 테이프 등으로 눈을 붙이고 살아가야만 한다. 또한 입술도 꽉 다물지 못하여 침을 질질 흘리게 된다. 혀의 반쪽도 안면신경이 담당하고 있어서 발음을 정확하고 또박또박 하지 못하게 되고, 밥 먹을 때도 혀가 원활하게 움직이지 못하여 식사를 잘 못하게 된다. 본 논문이 수술 이후에 이러한 환자 가 발생하지를 않는데 도움이 되었으면 한다. 신경외과, 신경과, 재 활의학과 의사선생님들은 다양한 여러 논문들에서 접해 볼 수는 있 을지 몰라도 수술장에서 직접 경험을 해보지 못한 분들이 훨씬 많 으리라 생각을 한다. 특히 검사를 담당하는 기사선생님들은 더욱 접하기 힘든 부분일 수 있다.

\section{본 논문에서는 크게 여섯 가지를 살펴보았다.}

첫 번째로 수술 중 신경손상이 발생할 때마다 바로 감지가 가능 한 자유진행 근전도 방법(spontaneous EMG, Free-running $\mathrm{EMG}$ ), 두 번째로 직접신경전기자극하여 신경과 뇌종양을 구별하 는 방법(triggered EMG, direct nerve electrical stimulation), 세 번째로 자유진행 근전도 파형을 네 가지로 세분화 하여 집도의에게 알리는 보다 정확한 신경학적상태파악 방법, 네 번째로 수술 중 환 자의 마취상태가 약해서 환자가 깨기 전에 미리 알 수 있는 세 가지 방법, 다섯 번째로 뇌종양과 안면신경의 구조를 크게 다섯 가지의 구조로 분류하여 생각하는 방법 그리고 마지막으로 여섯 번째로 수
술 후 안면신경이 정상인 경우와 안면마비가 발생한 경우의 비교를 살펴보았다.

위의 여섯 가지를 잘 숙지하여 수술환자의 행복한 삶에 조금이 나마 도움을 주었으면 한다.

\section{참고문헌}

Harner SG, Daube JR, Beatty CW, et al. Intraoperative monitoring of the facial nerve. Laryngoscope. 1998, 98:209-212.

Leonetti JP, Brackmann DE, Prass RL, Improved preservation of facial nerve function in the infratemporal approach to the skull base. Otolarvgol Head Neak Surg. 1989, 101:74-78.

Matthew L. Kircher, Jack M. Kartush. Pitfalls in intraoperative nerve monitoring during vestibular schwannoma surgery. Neurosurg Focus. 2012, 33(3):E5

Niparko JK, Kileny PR, Kemink JL, et al. Neurophysiologic intraoperative monitoring facial nerve function. Am J Oto. 1989, 10:55-61

Park SK, Lim SH, Park CW, Park JW, Kim DJ, Kim GB, et al. Intraoperative neurological monitoring and anesthesia. Korean J Clin Lab Sci. 2012, 44:184-198.

Traynelis VC, Gantz BJ, Intraoperative facial nerve monitoring. In: Loftus CM, Traynelis VC, eds. Intraoperative monitoring techniques in neurosurgery. New York: McGraw-Hill, Inc. 1994, 157-162.

서대원, 박관, 안재영, 이상구, 정진상, 홍승봉, 이원용, 김병준, 김종현. 소뇌 뇌교각 종양에서 수술 중 전기생리학적 신경계 집중감시의 변화. 대한신경 과학회지. 1999, 17(1):98-105.

서대원. 수술 중 신경계 감시에서의 유발전위검사. 대한임상신경생리학회지. 2007, 9(2):106-111. 